\title{
ECA compliance and enforcement - legal regime for ships
}

\author{
Dorota Pyć $^{1, *}$ \\ ${ }^{1}$ Maritime Law Department, Faculty of Law and Administration, University of Gdańsk
}

\begin{abstract}
This paper addresses the importance of the prevention air pollution from ships in terms of international legal compliance and enforcement. In addition to effectively enforcing international norms, standards and procedures, flag States have an obligation to prevent polluting ships from sailing. The International Convention for the Prevention of Pollution from Ships (MARPOL) has been described by the International Maritime Organization as "the most ambitious international treaty covering maritime pollution ever adopted". Annex VI of the MARPOL allows for the establishment of Emission Control Areas (ECAs). ECAs have been implemented to reduce the amount of air pollution from ships. The new ECA regulations entered into force on the $1^{\text {st }}$ of January 2015. First and foremost, this paper examines some aspects of the implementation of the new ECA regulations on shipping industry and control air emissions in the Baltic Sea ECA. Moreover, it outlines that Port State Control and Flag State Control are commitment to monitor and enforce compliance through inspections and penalties.
\end{abstract}

\section{Introduction}

Emissions generated in the combustion of marine fuels entering the air pollute the environment and have a significant negative impact on marine ecosystems. These emissions are a type of pollution from ships. Most often, in the legal doctrine pollution from ships (vessel-source pollution) is divided into: accidental, operational pollution and operational pollution by emissions (air pollution) [1]. Air emissions from ships have an impact on the processes of eutrophication and acidification of the seas and consequently threaten human health and the environment as an integrated whole. In particular, this applies to semi-enclosed seas as the Baltic Sea, which is also the special area and particularly sensitive sea area [2].

Reduction of air emissions from ships and the contribution of these emissions to global air pollution and environmental quality is one of the main objectives of the International Maritime Organization (IMO). IMO decided to create a policy to prevent air pollution in 1991 [3]. At that time, work was commenced on the development of a new annex to the International Convention for the Prevention of Pollution from Ships (MARPOL). The Marine Environment Protection Committee IMO (MEPC IMO) at the conference convened in London on September 1997 (Air Pollution Conference) presented the text of Annex VI Provisions on the Prevention of Air Pollution from Ships to the MARPOL, which was

\footnotetext{
*dpyc@prawo.ug.edu.pl
} 
adopted at the time together with the NOx Technical Code [4], which is mandatory for the application of Annex VI to MARPOL [5].

In 2008, IMO adopted amendments to Annex VI to the MARPOL (the 'revised MARPOL Annex VI') containing regulations for the prevention of air pollution from ships. The revised MARPOL Annex VI entered into force on 1 July 2010 and Article 1(6)(b) of Directive 2012/33/EU introduced one of the main changes of the revision, namely the mandatory use of marine fuels with a maximum $0,10 \%$ sulphur content in SOx-ECAs as of 1 January 2015, into the European Union law (Article 6(2) of Directive (EU) 2016/802). Similarly to the revised MARPOL Annex VI [6], Article 1(6)(c) of Directive 2012/33/EU also established the use of fuels with a maximum sulphur content of $0,50 \%$ in all other waters falling under the jurisdiction of a Member State ('European waters') outside the SOx-ECAs as from 1 January 2020 (Article 6(1) of Directive (EU) 2016/802) [7].

It should be emphasized that, the European Union is significantly interested in pollution prevention for many years, taking action to improve instruments for monitoring the air pollution from ships [8]. The main objective of the EU is to reduce the negative effects of the emission of air from ships and to ensure the proper functioning of the internal market in the field of shipping, EU ports and abatement technologies. In this respect, specific purposes include: (1) ensuring alignment of the EU law with the latest international standards and procedures for marine fuels, including advanced technical standards and technologies; (2) the definition of additional or alternative methods to limit the negative impact of emissions from shipping on human health and the environment; (3) strengthening the implementation of the monitoring and implementation system of EU law.

The purpose of this paper is assessment of the significance of selected legal instruments aimed at reducing harmful health effects and environmental damage caused by sulphur dioxide (SO2) emissions resulting from combustion of certain types of liquid fuels, as well as other air emissions from ships in the Baltic Sea area in the context of legal compliance. In addition, this article reviews recent developments at the Polish domestic law to promote compliance by ships with the ECA regime and enforcement at national level.

Although compliance and enforcement terms are sometimes used interchangeably, there are generally no major doubts as to what they mean in international law. Compliance is used in an international context while enforcement is used in a national one. In public international law, compliance is understood as the taking of effective action by state to meet an international obligation. Implementation of the international obligations is prerequisite for compliance. Legal compliance means that the state has made compliance of the domestic law with the international law (rules, standards and procedures). Proper implementation of legal standards should result in law enforcement in practice. Compliance refers to the situations in which a state is with regard to its obligations under MARPOL Annex VI. Enforcement refers to set of actions, which state (e.g. maritime administration) should take to ensure implementation of ECA standards. Enforcement of the MARPOL Annex VI can be exercise through ship inspections (flag state inspection or port state inspection) to ensure that ships fulfill technical norms and monitoring ship compliance and by punishing non-compliance ships [5].

There are some instruments to promote compliance inter alia inspections, reporting and monitoring compliance. Inspections and fuel sampling are actions to be taken at national level to enforce compliance with the ECA regime. In order to assess the significance of these selected legal instruments for the control of air emission standards, a normative analysis was used. In addition to dogmatic research, empirical research has become particularly important in order to justify legal decisions by European Union institutions.

Reporting on compliance with air emission standards from ships and inspections of compliance with sulfur content standards in marine fuels are international instruments introduced into domestic law by the State-Parties to Annex VI of MARPOL and required by 
the European Union law. Both of these instruments are used to monitor compliance with international standards. Reporting as well as inspections allows assessing the degree of compliance of obligated entities to comply with certain rules, standards and procedures.

\section{Selected legal instruments for the control of air pollution from ships}

The definition of the Emission Control Area (ECA) is contained in Regulation 2 of MARPOL Annex VI. The ECA means an area where the adoption of special mandatory measures for emissions from ships is required to prevent, reduce and control air pollution from NOx or SOx and particulate matter or all three types of emissions and their attendant adverse impacts on human health and the environment. Emission Control Areas shall include those listed in, or designated under, regulations 13 and 14 of Annex VI.

Effective preparation is essential to safeguard a global level-playing-field for operators and to reduce air pollution from ships across the world. For ships operating outside designated the Emission Control Areas, IMO has set a limit for sulphur in fuel oil used on board ships of $0.50 \% \mathrm{~m} / \mathrm{m}$ (mass by mass) from 1 January 2020 . This will significantly reduce the amount of sulphur oxide emitted from ships and should have major health and environmental benefits for the world, particularly for populations living close to ports and coasts. Ships must be issued with an International Air Pollution Prevention Certificate (IAPP) by their Flag State. This certificate includes a section stating that the ship uses fuel oil with a sulphur content that does not exceed the applicable limit value as documented by bunker delivery notes or uses an approved equivalent arrangement. Port and coastal States can use Port State Control to verify that the ship is compliant.

\subsection{Reporting on compliance with air emission standards from ships}

Reporting on compliance with air emission standards from ships and preparing for the enforcement of the global $0.50 \%$ sulphur cap are to be an active support increasing the sustainability of maritime transport in the European Union.

The Council Directive 1999/32/EC relating to a reduction in the sulphur content of certain liquid fuels was amended several times. Last time it has been changed by Directive 2012/33/EU of 21 November 2012 as regards the sulphur content of marine fuels [7]. In order to ensure consistency of the Directive, it was codified in Directive (EU) 2016/802 relating to a reduction in the sulphur content of certain liquid fuels [7].

Article 14(1) of Directive (EU) 2016/802 requires EU Member States to submit each year by 30 June a report to the Commission outlining compliance with the sulphur standards of the liquid fuels falling within the scope of the Directive on the basis of checks carried out in the preceding year. Article 14(1) furthermore requires the Commission to evaluate the need for further strengthening of the relevant provisions of the Directive and to make any legislative proposals to that effect. On the basis of these national reports and on the notifications regarding the non-availability of marine fuels, the Commission shall each year report on the implementation of the Directive.

The EU Member States are obliged to take action against fuel suppliers that have been found to deliver marine fuel that does not comply with the specification on the bunker delivery note and to maintain a publicly available register of suppliers of marine fuels to increase transparency. Member States are also required to control marine fuel suppliers by taking samples of their products upon delivery to a ship in case of recurrent reports of alleged quality issues ('letters of protest') (Article 4 of Implementing Decision (EU) 2015/253) [9]. 


\subsection{Mandatory frequency of inspections and fuel sampling}

Mandatory frequency of inspections and fuel sampling ensure an equal enforcement burden among Member States and a level-playing-field for the European Union ports and operators. Physical sampling of marine fuels being used by ships for the purpose of verifying their sulphur content should be carried out either by analyzing the sealed 'bunker sample' or the 'representative sample' accompanying the bunker delivery note and available on-board, or by obtaining and analyzing a 'fuel spot sample' drawn from the ship's fuel service system [9].

To ensure an equal enforcement burden among Member States and a level-playing-field for the EU ports and operators, Directive 2012/33/EU empowered the Commission to define a binding frequency of inspections and sampling of marine fuels (Article 13(4) of Directive (EU) 2016/802), which was laid down in the Implementing Act [10].

The EU Member States have to complement the documentation check by sampling and analyzing the sulphur content of the fuels of 20 to $40 \%$ of the inspected ships depending on whether the Member State is (partly) bordering a SOx-ECA or not [9].

\subsection{Polish Legal Perspective}

The provisions of the Polish Act on prevention pollution from ships from 1995 [11] ensure compliance with Annex VI of the MARPOL and implementation of the requirements of the Directive 2016/802 [7].

According to the Polish Act on prevention pollution from ships (Article 13c) [11], the use of marine fuel which does not meet the requirements or additional qualitative criteria are prohibited on ships of the Polish nationality and ships of foreign nationality in Polish maritime areas. Emission abatement methods may be used on ships of the Polish nationality or ships of foreign nationality in Polish maritime areas as an alternative to using marine fuels that meet the requirements and additional qualitative criteria. Emission abatement method means the use of any fitting, material, device to be fitted in a ship or other procedure, alternative fuel, or method, ensuring the reduction of sulphur dioxide emission that is verifiable, quantifiable and enforceable. The minimum criteria to be met by emission abatement methods are laid down in Annex II to the Council Directive 1999/32/EC (as amended) [7]. On ships which use emission abatement methods, sulphur dioxide emission abatement should be achieved on an ongoing basis to at least the level equivalent to the value of sulphur dioxide emission that would be achieved using marine fuel that meet the requirements and additional qualitative criteria. Equivalent emission values for sulphur dioxide are laid down in Annex I to the Directive 1999/32/EC [7]. For ships at berth in ports, the use of onshore power supply systems, if available in a given port, can be allowed as an alternative solution to emission abatement methods.

The Act specifies the competences of the director of the maritime office in the field of keeping records of fuel suppliers. The director is required to keep the register of suppliers of marine fuel, operating in Polish maritime areas (Article 13e). Before the first delivery, the supplier is obliged to notify the director of the maritime office competent for the place of delivery about the fuel supply activity in Polish maritime areas. The notification should include the name, seat, address for correspondence and telephone number of the supplier, a copy of the fuel trading license, and should specify the types of supplied fuels. The supplier must inform the director of the maritime office about the change of data within 30 days from the date of the change.

By 31 March each year, the supplier is obliged to submit the report from activity in the previous year, including at least the information about the quantity and type of fuel sold in individual ports, taking into account the sulphur content, to the director of the maritime office 
competent for the place of delivery. If the supplier ends fuel supply activity in Polish maritime areas, the supplier must notify the director of the maritime office competent for the place of delivery in writing about it, within 30 days from the completion of the activity. The director of the maritime office provides the list of suppliers available to the public in the Public Information Bulletin at the website of maritime office. The list includes names of suppliers, their seats, and addresses for correspondence, telephone numbers and specification of the types of fuels supplied.

According to the Article $13 \mathrm{f}$ of Polish Act on prevention pollution from ships the supplier is obliged to deliver fuel that meets the requirements for sulphur content of marine fuel, including the method of its labelling as well as additional qualitative criteria for marine fuels supplied to ships, to protect the environment against pollution from ships, laid down in the provisions specified in Polish implementing regulations.

Detailed obligations of the supplier and the master of the ship regarding fuel delivery to the ship are specified in the MARPOL Convention. If the master of the ship of the Polish nationality outside Polish maritime areas cannot purchase marine fuel with sulphur content allowed in a given maritime area, the master shall notify about this the director of the maritime office competent for the home port of the ship and the competent authorities of the port of destination. If the master of the ship in Polish maritime areas cannot to purchase marine fuel with sulphur content allowed in those maritime areas, the master shall notify about this the director of the maritime office competent for the area where the ship is, the administration of the country of the ship's nationality and the competent authorities of the port of destination.

The director of the Polish maritime office, as a governmental maritime authority, is competent to perform inspections of sulphur content of marine fuel on ships (Article 13g).

The inspection regarding the sulfur content of marine fuel is carried out in accordance with art. 3-6 of Decision 2015/253 (Implementing Act) [10] and includes: checking each time fuel delivery documents containing information of the fuel supplier with sulfur content in marine fuel, including checking whether sealed marine fuel samples accompanied by these documents are signed by the representative of the vessel accepting the fuel, and checking the machine log and oil record book regarding entries documenting operations change of fuel; for at least $40 \%$ of inspected vessels downloading marine fuel samples: (a) from the on-board fuel circulation system, (b) from the vessel's fuel tank, if technically possible, (c) using sealed marine fuel samples accompanying fuel delivery documents, transferred to the ship by the fuel supplier in accordance with regulation 18 of Annex VI to the MARPOL Convention or (d) during its delivery to the ship - and testing the sulfur content in it.

In the case of taking marine fuel samples on board in accordance with the provisions of Decision 2015/253 (Implementing Act) [10], the ship's representative shall keep one sample for a period of not less than 12 months from the date of its collection. As a result of an inspection, that a ship does not comply with the requirements for the sulfur content of marine fuel, the director of the maritime office shall request the master of that vessel: (1) if possible, take measures to adapt marine fuel to the implementing applicable regulations; (2) the presentation of: (a) a list of measures taken to comply with the requirements concerning the sulfur content of marine fuel in a given sea area, (b) proof that an attempt has been made to purchase marine fuel with a sulfur content permissible in a given sea area in accordance with the itinerary and, if the fuel was not available at the place where it was planned to be purchased, an attempt was made to locate alternative sources of such fuel, and that, despite such attempts, it was not possible to purchase such fuel.

Proof of attempted acquisition of marine fuel with the content of acceptable sulfur in a given sea area is considered a written statement from the fuel supplier about the lack of 
availability of such fuel in a given port. The director of the maritime office shall take into account the ship's voyage plan, including the planned date of leaving the port.

Information about the results of the ship inspection carried out in the field sulfur content in marine fuel include: (1) the date of the inspection carried out; (2) vessel identification data: identification number given by the International Maritime Organization, name, affiliation, reconnaissance signal, gross tonnage (GT), type of propulsion, emission reduction methods, if different from those based on the use of low-sulfur fuels; (3) the names of the fuel tanks owned by the ship and their determination capacity; (4) specification of the type of combustion device and its power specified in $\mathrm{kW}$; (5) data on marine fuel delivered on a ship obtained from fuel delivery documents or on on the basis of the journal entries: date of fuel delivery, fuel type, quantity in $\mathrm{m}^{3}$, sulfur content in \%, name of the fuel supplier and name of the fuel delivery port; (6) data from the International Air Pollution Prevention Certificate (IAPP): name of the authority that issued the certificate, date of issue, date the name of the body that carried out the periodic inspection confirming the validity of the certificate, and the date and place of the last periodic inspection; (7) data on the marine fuel sample taken: fuel type, number in $\mathrm{ml}$, sulfur content in $\%$, sampling source, sampling method, sample identification number, name of the port in which the sample was taken, and date of sample analysis and laboratory name analysis of the sample; (8) non-compliance with the requirements regarding the content of sulfur in the fuel has been found shipping, including type of deficiencies, and actions taken to achieve compliance; (9) other data obtained during the inspection.

The director of the maritime office draws up a report from inspections each year. The report contains results of analysis of sulphur content and is submitted to the President of the Office of Competition and Consumer Protection by 30 April of the following year. The report should include in particular the information about: total number of analysed samples by type of fuel; fuel quantity used for the analysis each time and the determined average sulphur content; number of inspections on ships; average sulphur content of marine fuels used in the area of competence of the director of the maritime office, calculated based on performed analyses and information provided by fuel suppliers. The minister responsible for maritime economy should ensure that the information referred to in Article 7 of Decision 2015/253 (Implementing Act) [10] is forwarded to the European Commission by 30 June each year.

The shipowner whose ship polluted the marine environment when in Polish maritime areas in breach of the Act in connection with ship operation is liable to a fine being the equivalent of 1,000,000 reference units called Special Drawing Rights (SDR) defined by the International Monetary Fund. This penalty can be also imposed on the shipowners of Polish nationality ships which polluted the marine environment in breach of the Polish Act on prevention pollution from ships outside Polish maritime areas, in connection with ship operation (Article 36).

If a shipowner fails to exercise the obligations stipulated by the law or violates prohibitions established by the law by using fuel with impermissible sulphur content on a ship shall be liable to a fine of 600,000 SDRs. If the shipowner applies emission reduction methods on board, without the approval required for them, shipowner shall be subject to a penalty of up to SDR 600,000 . If the shipowner does not pass the results of tests of emission abatement methods in accordance with the prescribed procedure, shipowner shall be subject to a penalty of up to 100,000 SDRs. (Article 36aa).

The supplier who fails to fulfil the obligation defined in Article 13e(2)-(5) and Article $13 \mathrm{f}$ when supplying fuel shall be liable to a fine of 50,000 SDRs (Article 36c).

In accordance with Article 37, if a master or any other crew member inter alia: (1) fails to exercise the obligations stipulated by the law and fails to keep the records of each instance of switching to a different fuel in line with the requirements of the MARPOL Convention; (2) does not have nautical delivery documents on board in the ship's fuel tanks or documents 
do not contain all information required in accordance with the MARPOL Convention; (3) does not carry on-board marine fuel samples in the ship's fuel tanks or marine fuel samples are not sealed or unsigned (non-compliance with MARPOL); (4) does not have the required documents (Article 13g); (5) does not have a valid permit for testing emission reduction methods or does not meet the legal requirements; (6) uses emission reduction methods on a ship in a manner that does not ensure reduction of emissions required by law - shall be liable to a fine whose amount does not exceed 20 times the average salary in the national economy for the preceding year, published by the President of the Central Statistical Office.

\section{Conclusions}

The International Maritime Organization plays a leading role in promoting legal instruments of a preventive nature. Legal measures are essential to prevent pollution from ships. In 1997, the Annex VI "Regulations for the prevention of air pollution from ships" was added to MARPOL Convention to minimize emissions form ships [12]. Since then, the system of legal instruments aimed at reducing harmful emissions from ships has been considerably strengthened. The IMO and the European Union strive to achieve international legal compliance, i.e. coherence of the norms of national law with international law. In 2012 the European Commission adopted more detailed provisions on the content and format of the annual reports of Member States. The Directive 2012/33/EU has introduced many changes , e.g. the mandatory use of low sulphur marine fuels in the Baltic Sea designated as Sulphur Oxides Emissions Control Areas, took effect only on 1 January 2015.

The EU has an important role to play in compliance reinforcement through the mandatory frequency of inspections and fuel sampling, as well as monitoring compliance and the development of reporting mechanisms of the EU Members States' conduct. Reporting on compliance with air emission standards from ships aims at exchanging information between the Commission and the EU Member States. Reporting is closely related to monitoring compliance. Frequency is determined by the annual number of individual ships calling in port of the EU Member State. According to Implementing Act [10], all Member States may carry out inspections of the ship's documentation on at least $10 \%$ of the individual ships calling in their ports. Member States have to complement the documentation check by sampling and analysing the sulphur content of the fuels of 20 to $40 \%$ of the inspected ships depending on whether the Member State is bordering a SOx-ECA or not. The frequency of sampling in the SOx-ECA areas is higher than that in other European waters.

Polish law is in compliance with international law contained in Annex VI of the MARPOL Convention as well as the European Union law on the prevention of air pollution from ships. In the last few years, the Polish Act on Prevention Pollution from Ships has been amended several times. The Act was last amended in 2017. International legal compliance is undervalued, however at national level particular attention must be paid to proper implementation and law enforcement.

\section{References}

1. E.J. Molenaar, Coastal State Jurisdiction over Vessel-Source Pollution, Kluwer Law International, The Hague/Boston/London, p. 19 (1998)

2. A. Lähteenmäki-Uutela, S. Repka, T. Haukioja, T. Pohjola, How to recognize and measure the economic impacts of environmental regulation: The Sulphur Emission Control Area case, Journal of Cleaner Production 154, 553-565 (2017) 
3. IMO Res. A.719(17)

4. MEPC.177(58)

5. M. Fitzmaurice, The International Convention for the Prevention of Pollution from Ships (MARPOL), [in:] IMLI Manual on International Maritime Law, vol. III Marine Environmental Law and Maritime Security Law, gen ed. D.J.Attard, ed. M. Fitzmaurice, N. A Martínez Gutiérrez, R. Hamza, Oxford University Press, p.55, pp. 61-63 (2016)

6. http://www.imo.org/en/OurWork/Environment/PollutionPrevention/AirPollution/Page s/Index-of-MEPC-Resolutions-and-Guidelines-related-to-MARPOL-Annex-VI.aspx

7. Council Directive 1999/32/EC relating to a reduction in the sulphur content of certain liquid fuels has been substantially amended several times, lastly by Directive 2012/33/EU of 21 November 2012 as regards the sulphur content of marine fuels, OJ L 327 of 27.11.2012, p. 1, which entered into force on 17 December 2012 and had to be transposed by 18 June 2014 . To preserve clarity and rationality following the different substantial amendments of Council Directive 1999/32/EC, it was codified as Directive (EU) 2016/802 of 11 May 2016 relating to a reduction in the sulphur content of certain liquid fuels, OJ L 132 of 21.5.2016, p. 58.

8. J. Harrison, Atmospheric Pollution of the Marine Environment [in:] IMLI Manual on International Maritime Law, vol. III Marine Environmental Law and Maritime Security Law, gen ed. D.J.Attard, ed. M. Fitzmaurice, N. A Martínez Gutiérrez, R. Hamza, Oxford University Press, pp. 190-191 (2016)

9. Report from the Commission to the European Parliament and the Council on implementation and compliance with the sulphur standards for marine fuels set out in Directive (EU) 2016/802 relating to a reduction in the sulphur content of certain liquid fuels, European Commission Brussels, 16.04.2018 COM(2018)188 final.

10. Implementing Act: Commission Implementing Decision (EU) 2015/253 of 16 February 2015 laying down the rules concerning the sampling and reporting under Council Directive 1999/32/EC as regards the sulphur content of marine fuels, OJ L 41 of 17.2.2015.

11. Polish Act on Prevention Pollution from Ships, 16.03.1995, consolidated text: Journal of Laws 2017, item 2000

12. D. Pyć, Uwagi de lege ferenda o statusie Morza Bałtyckiego jako obszaru kontroli emisji tlenków azotu ze statków morskich, Prawo Morskie t. XXVIII, 235-247 (2012) www.journals.pan.pl/delibra/journal/107532?language $=$ en 